\title{
Natural dyes and dyeing techniques used by craftswomen in the Northern Hhohho region of Swaziland
}

\author{
Elsje S Toerien* \& Siqondile Khumalo
}

\begin{abstract}
OPSOMMING
Daar was die afgelope paar dekades 'n aansienlike toename in belangstelling in natuurlike kleurstowwe. Dit kan hoofsaaklik daaraan toegeskryf word dat natuurlike kleurstowwe as meer omgewingsvriendelik as sintetiese kleurstowwe beskou word. Baie lande het streng wette en regulasies afgekondig om die gebruik van kleurstowwe wat karsinogeniese stowwe bevat, te reguleer (Purohit, et al, 2007; Deo \& Desai, 1999; Hill, 1997; Sarkar \& Seal, 2003; Siva, 2007). Daar is egter ' $n$ ongerustheid en bekommernis oor die verlies aan kennis oor natuurlike kleurtegnieke. Dit wil voorkom of nog net ouer handwerkers in tradisionele stamverwante gemeenskappe oor hierdie kennis beskik (Kala, 2002; Mahanta \& Tiwari, 2005; Siva, 2007). Dube en Musi (2002) asook Long (2005) het die behoefte uitgespreek dat die inheemse kennis in Swaziland gedokumenteer word voordat dit vir altyd verlore gaan. Dominique Cardon, wêreldoutoriteit oor natuurlike kleurstowwe, het ook aangedui dat daar min inligting oor die gebruik van natuurlike kleurstowwe in Suider-Afrika bestaan. Die doel van die studie was om die natuurlike kleurstowwe en gebruike van handwerkers in die noordelike Hhohho-streek van Swaziland te ondersoek en te identifiseer.
\end{abstract}

Daar is verrassende ooreenkomste tussen verskillende beskawings ten opsigte van kleurtegnieke en plante (Cardon, 2007:1). Dit sou dus interessant wees om te sien of dieselfde of soortgelyke plante en tegnieke as wat in Swaziland gebruik word, ook elders in Suider-Afrika of die wêreld benut word. Dit is dus ook nodig om te verifieer of die geïdentifiseerde plante wel deur ander skrywers as bron van kleurstof erken word.

Die navorsing kan as ondersoekend en beskrywend bestempel word. Die navorsingsmetode is soortgelyk aan dié van ander ondersoeke wat ten doel gehad het om inheemse kennis van tradisionele handwerkers te dokumenteer (Doğan et al, 2003; Dube \& Musi, 2002; Kala, 2002; MacFoy, 2004). Gedurende 2007 en 2008 is fokusgroeponderhoude gevoer met 'n groep van vyftien handwerkers van die Ngimanodolo-gebied, naby Piggs Peak in Swaziland, wat steeds natuurlike kleurstowwe gebruik. Hulle het hul kleuringstegnieke beskryf en ook 19 soorte plante wat hulle gebruik, geïdentifiseer. Addisionele inligting, soos die deel van die plant wat gebruik word, die kleur wat verkry word, en die tye van die jaar wanneer die plante geoes word, is ook ingewin.

Gedurende 'n besoek aan Swaziland in 2009 is ' $n$ intensiewe ondersoek gedoen van handwerkartikels wat in die Ezulwini-omgewing te koop aangebied word. Geen bewys van die gebruik van natuurlike kleurstowwe kon gevind word nie. Daar is ook gevind dat die Ngimanodolo-groep, ná die afsterwe van hulle leier, ook die gebruik van natuurlike kleurstowwe gestaak het. 'n Klein groepie met kennis van tradisionele kleurstowwe is in die Mshingishi-gebied gevind. Foto's van die blare, blomme, vrugte, bas en groeiwyses van die plante wat deur die Ngimanodologroep geïdentifiseer is, is aan hulle gewys. Die Mshingishi-groep het agt van die plante wat deur die Ngimanodolo-groep gebruik is, herken as bron van kleurstowwe. Hulle het sewe van hierdie plante ook dikwels gebruik. Daar is gevind dat albei groepe die direkte kleurmetode gebruik. Plantmateriaal word versamel en dan met behulp van klippe in klein stukkies opgebreek. Die vergruisde materiaal word saam met die grasse of reeds gespinde draad in water gekook.

Ses van die plante (Antidesma venosum, Bauhinia galpinii, Calpurnia aurea, Ilex mitis, Sterculia murex en Ziziphus mucronata) wat deur die Ngimanodologroep identifiseer is, word deur slegs een ander bron (Dube \& Musi, 2002) gelys, maar geen addisionele inligting oor die plante word deur hierdie bron verskaf nie. Daar kan dus gesê word dat hierdie studie inligting ingewin het wat gevaar geloop het om vir altyd verlore te gaan.

\section{- Prof ES Toerien*}

Department of Life and Consumer Sciences University of South Africa

Tel: +27(0)114712292

Fax: +27(0)114712796

e-mail: toeries@unisa.ac.za

${ }^{*}$ Corresponding author

- Ms S Khumalo

Deparment of Life and Consumer Sciences University of South Africa 


\section{INTRODUCTION}

Prior to the discovery of synthetic dyes by William Henry Perkin in 1856, all dyeing was done with dyestuffs of natural origin. Due to the favourable characteristics of synthetic dyes, such as the vast range of colours obtainable, the ability of reproducing a specific colour and the lower costs involved, they had all but replaced natural dyes in commercial textile dyeing by the middle of the 20th century (Bechtold et al, 2006; Gilbert \& Cooke, 2001; Gulrajani, 2001). However, the last decade or two has seen an increase in interest in natural dyes. This is mainly because natural dyes are seen as being more environmentally friendly. Strict environmental laws and regulations have been imposed by many countries to govern the use of synthetic dyes, particularly those containing carcinogenic substances (Deo \& Desai, 1999; Purohit, et al, 2007; Hill, 1997; Sarkar \& Seal, 2003; Siva, 2007). Furthermore, synthetic dyes are manufactured from by-products of fossil fuels, a non-renewable resource, while dyes of plant origin are considered to be a renewable product (Bechtold et al, 2006; Bechtold et al, 2007; Gilbert \& Cooke, 2001). Natural dyes are also representative of the consumers' interest in organic products and emphasis on a more natural way of life (Sarkar \& Seal, 2003).

\section{JUSTIFICATION AND PURPOSE OF THE STUDY}

With the increase in use of synthetic dyes, and the subsequent decrease in practising natural dyeing techniques, even among traditional and ethnic craftspeople, there is a growing concern over the loss of indigenous knowledge of dyeing processes. It seems that this knowledge now remains only with the surviving older people and dyers in tribal communities (Kala, 2002; Mahanta \& Tiwari, 2005; Siva, 2007). Both Dube and Musi (2002) and Long (2005) expressed the need to document Swazi indigenous knowledge before it was lost for ever. In a 2007 email Dominique Cardon, a world renowned authority on natural dyes, stated that she lacked recent information on dyeing practices in South Africa and neighbouring countries and that dye plants "only barely remembered by elderly persons in remote areas" should be studied and documented before knowledge of them disappears.

A study on Swazi indigenous knowledge systems (Dube \& Musi , 2002) found that the use of natural dyestuffs during handcraft production was prevalent in the Hhohho region. Cardon (2007:1) also remarks on the amazing similarity that exists across different civilisations in techniques and plants used for dyeing purposes. A relatively restricted variety of plants are also used. Apart from the publications by Cunningham and Milton (1987); Cunningham, (1987 \& 1994); and Van Wyk and Gericke (2000:246-259), little research has been done on natural dyes used by traditional crafters in southern Africa. It would therefore be interesting to see if the same or similar plants and techniques to those used in Swaziland are used elsewhere in southern Africa, or for that matter in the world.
The purpose of this study was therefore to explore the natural dyes and dyeing practices used by craftswomen from the northern Hhohho region of Swaziland. In addition to identifying the natural dye-yielding plants used by a group of craftswomen in the northern Hhohho region of Swaziland and documenting the dyeing processes and techniques used, a third objective, namely to authenticate the use of the identified plants as a source of dye, was formulated. It is the hope of the researchers that such studies would help retain the extremely valuable but fragile indigenous knowledge on natural dyes and dyeing techniques from Swaziland.

\section{LITERATURE REVIEW}

Natural dyes have been researched in a wide range of possible applications. Recent studies include nontextile applications such as historic maps and drawings (Blanc et al, 2006), art and archaeological materials (Casas-Catalán \& Doménech-Carbó, 2005; Karapanagiotis, 2006) and the colouring of hair and skin (Dweck, 2002) as well as textile applications such as historic textiles ( Ferreira et al, 2004; Surowiec et al, 2006), and the dyeing of cotton yarn (Cristea \& Vilarem, 2006; Gulrajani et al, 2001), cotton and jute fabrics (Deo \& Desai, 1999), flax fabrics (Sarkar \& Seal, 2003), wool used in rug and carpet weaving (Doğan et al, 2003; Kala, 2002), and sheep, goat and Angora rabbit wools and silk (Akçakoca Kumbasar et al, 2009). In southern Africa, however, natural dyes were mostly used to provide colour to basket-weaving materials such as fibres from the Hyphaene palm, Agave sisalana, or other grasses or grass-like plants (Cunningham, 1987; Cunningham \& Milton, 1987; Van Wyk \& Gericke, 2000:247).

Although natural dyes can, per definition, be obtained from animal, vegetable or mineral sources, by far the largest percentage are from plant origin. Cardon (2007:551) describes only 25 animal species used to produce dyes, compared to hundreds of plant species. No reference to animal dyes used in southern Africa could be found. Natural dyes differ from synthetic dyes in that, while synthetic dyes usually consist of a single molecule lending colour, natural dyes contain different colorants in the same plant. It is this characteristic that gives natural dyes their richness and diversity of colour and shade (Cardon, 2007:xiii Purohit, et al, 2007;). Unfortunately, natural dyes are substantive: they often form only a weak bond with the textile being dyed, and need a mordant that creates a chemical bond between the dye and the fibre, making them insoluble once they have penetrated the fibres and therefore colourfast to washing (Ferreira et al, 2004; Vankar, 2000; Van Wyk \& Gericke, 2000:247). Depending on the mordant used, a variety of different shades can be obtained from the same dye plant. This is illustrated very effectively in both Cardon (2007:5) and Van Wyk and Gericke (2000:253, 259).

Natural dyes are classified as vat dyes, mordant dyes or direct dyes, depending on the technique used during the dyeing process (Cardon, 2007:4; Ferreira et 
al, 2004; Hill,1997).

\section{Vat dyes: indigo and shellfish purple}

These dyes are normally not soluble in water; they have to be made soluble during a reduction process. This takes place in dye-baths or vats, the contents of which must be kept at a temperature of $50{ }^{\circ} \mathrm{C}$ over long periods of time. The vats are often partly buried in order to control the temperature. In their soluble form the dyes have a light greenish-yellow colour, referred to as "white indigo" by Polakoff (1982:31), but once exposed to the oxygen in the air, they are oxidised to their insoluble form and the blue or purple pigments are trapped within the fibres (Cardon, 2007:4, 336; Ferreira et al, 2004; Polakoff,1982:30, 31).

Vat dyeing requires a complex procedure and does not seem to be used extensively in southern Africa. Dube and Musi (2002) do not mention an indigo containing plant in their list of dye plants from Swaziland, but Long (2005) names both Indigofera confusa and Indigofera tinctoria as sources of indigo dye.

\section{Mordant dyes}

As mentioned before, most natural dyes need a mordant in order to bind strongly with the textile being dyed. These are usually metallic salts of aluminium, iron, copper, tin or chromium (Cardon, 2007:20-49; Deo \& Desai, 1999; Feng et al, 2007; Türkmen et al, 2004). Mordanting can take place before dyeing, simultaneous with dyeing, or post-dyeing.

\section{Direct dyes}

There are also those dyes that need no mordant. The dyestuff seems to have a strong enough affinity for the textile. These are called substantive dyes (Siva, 2007). The plant material is boiled beforehand and the resulting tea then strained and used as dye, or the material to be dyed is boiled with the plant material, often for several hours. This direct dyeing method is used by basket weavers from the tri-state area at the confluence of the Sashe and Limpopo Rivers (Mokwena, 2008).

\section{RESEARCH METHOD}

This research into the dyeing practices of craftswomen of the Hhohho region can be said to be exploratory and descriptive in nature. Research methods followed are similar to those used in other surveys documenting indigenous knowledge of traditional craftspeople (Doğan et al, 2003; Dube \& Musi, 2002; Kala, 2002; MacFoy, 2004).

\section{Focus group interviews: Ngimanodolo group}

A group of craftswomen from the Ngimanodolo village near Piggs Peak, Swaziland, that still used natural dyes was identified. During 2007 and 2008 several focus group interviews were conducted with this group by a researcher from the area who was familiar with their language and customs. Focus groups are considered to be particularly useful for exploratory research where very little is known about the phenomenon being investigated. The term "focus" indicates that only a small number of issues are discussed during the interviews. One of the main advantages of focus group interviews is that they allow members other than the leader to respond to and build upon information supplied (Stewart \& Shamdasani, 1990:15-16).

Open ended questions were used to establish:

- which materials were dyed by the women, where and how they obtained them, and what they were used for;

- which plants were used during the dyeing process, which part of each plant was used, which colour was obtained, and during which months of the year was a particular species harvested;

- which techniques and mordants were used during dyeing; and

- what their thoughts and feelings on the documentation of their indigenous knowledge on natural dye were.

\section{Survey of craft markets}

During visits to Swaziland in September 2009 and February 2010, intensive surveys of the craft markets in and around Ezulwini and the northern Hhohho region were undertaken and the salesladies queried in detail about the materials used to make, in particular, the popular titja baskets.

\section{Focus group interviews: Mshingishi group}

As no evidence of naturally dyed materials could be found during the survey of the craft markets, it was considered wise to revisit the original group of craftswomen. It was found that the leader of the original group had passed away and that the remaining ladies were reluctant to talk about previous methods used. This could be in part out of a respect for the dead, but it could also be because some of them were now weaving titja baskets for Tintsaba, an internationally recognised concern that supplied them with the already dyed sisal thread. They were very clearly afraid of parting with any information lest they lose their jobs. By making a number of enquiries, one leading to the other, a lady, Ms Ngwenya, from the Mshingishi area to the north of Piggs Peak was identified. Although she also wove baskets for Tintsaba, she was willing to be interviewed and also dye and weave a small basket for the researcher.

Illustrations and photographs of the leaves, flowers, fruits, bark and complete plant of the 19 plants identified by the Ngimanodolo group were obtained and printed in colour, one plant per A4 sheet. Both the researchers visited Ms Ngwenya in February of 2010. She was shown the illustrations and, with her daughter-in-law and two others (referred to as the Mshingishi group) were questioned on their knowledge of the particular plant as a source of dye. Immediately after 
leaving Ms Ngwenya, the two researchers retired to a quiet place and reviewed the illustrations and the notes made during the interview. The Swazi researcher then supplied additional information gleaned not only from the ladies' conversations between themselves but also from their body language.

\section{RESULTS AND DISCUSSION}

The results obtained during the interviews with the two groups, as well as the survey of the craft markets, will be described in brief and then followed with a detailed discussion of the results as per objective of the study.

\section{Results: Ngimanodolo group}

The group described the techniques they used, and identified 19 plants used as dye sources. They supplied additional information such as the part of the plant used, the colour obtained and the time of year when the dyestuff could be harvested. The women supplied the common siSwati names for plants. Supplying the correct botanical name for the siSwati name is a problem also encountered by Long (2005). SiSwati names differ from one part of the country to the next, and often the same name is used for a number of subspecies of the same plant. Vernacular names are not bound by rules as botanical ones are, and one therefore cannot say that a common name is incorrect (Van Jaarsveld, 2007). In this case the scientific names were obtained from a botanist familiar with the dye plants used in the area, and by crossreferencing other publications.

\section{Results: Craft markets survey}

Many of the salesladies were familiar with the methods used in making the baskets, having either made the baskets themselves or obtained them from family or friends who made them. Although valuable information on the grasses used to weave the artefacts were obtained, no evidence of naturally dyed materials could be found. Instead the researcher was shown small bottles of concentrated synthetic dyes. Those that could remember plants used for dyeing could only name the Umganu (Marula) tree as a favourite of their mothers or grandmothers.

\section{Results: Mshingishi group}

The ladies identified seven of the 19 plants used by the Ngimanodolo group as sources of dyestuff used by them at some stage in the past, and one other as a known source of dye, although not used by them. They were not questioned in detail on their dyeing techniques, but Ms Ngwenya did show the researchers how the titja baskets were woven. Both groups expressed concern about the fact that the indigenous knowledge on dyeing was not preserved, and that the younger generation did not practise most of the older crafts any more. They expressed their satisfaction with the fact that the researchers will publish some of this knowledge. Ms Ngwenya would have preferred to continue using natural dyes collected by the group themselves, feeling that using only already dyed yarns supplied to her disempowered her and took a certain measure of control away from her. But as she had neither the knowledge nor the means to market her products herself, she had to rely on what was available to her.

\section{Dyeing processes and techniques}

Both the Ngimanodolo and the Mshingishi group made their baskets by winding sisal thread around tufts of lutindzi (coleochloa setifera) grass. Lutindzi grass is a perennial, growing up to $60 \mathrm{~cm}$ high and at an altitude of up to $2150 \mathrm{~m}$ (Germishuizen et al, 2006:924). In Figure 1 the weaving of a basket can clearly be seen.

The sisal is obtained from sisal plants (Agave sisalana) that are planted as cattle fences. The leaves are harvested and the fibres removed from the flesh. The fibres are then washed and dried. The sisal yarn is spun by rolling it on the thigh by hand. All processing of the sisal yarn is done by hand. With neither of the two groups did the weavers spin their own yarn. The Ngimanodolo weavers bought their undyed yarn in Manzini, while the Mshingishi weavers, when working on contract, were supplied with dyed and processed yarn by their Tintsaba contacts.

Both groups used a direct dyeing method similar to that of the basket makers from the Sashe-Limpopo area. The plant material is collected and then pounded and crushed to maximise the extraction of the dyestuff. The crushed materials are placed in a

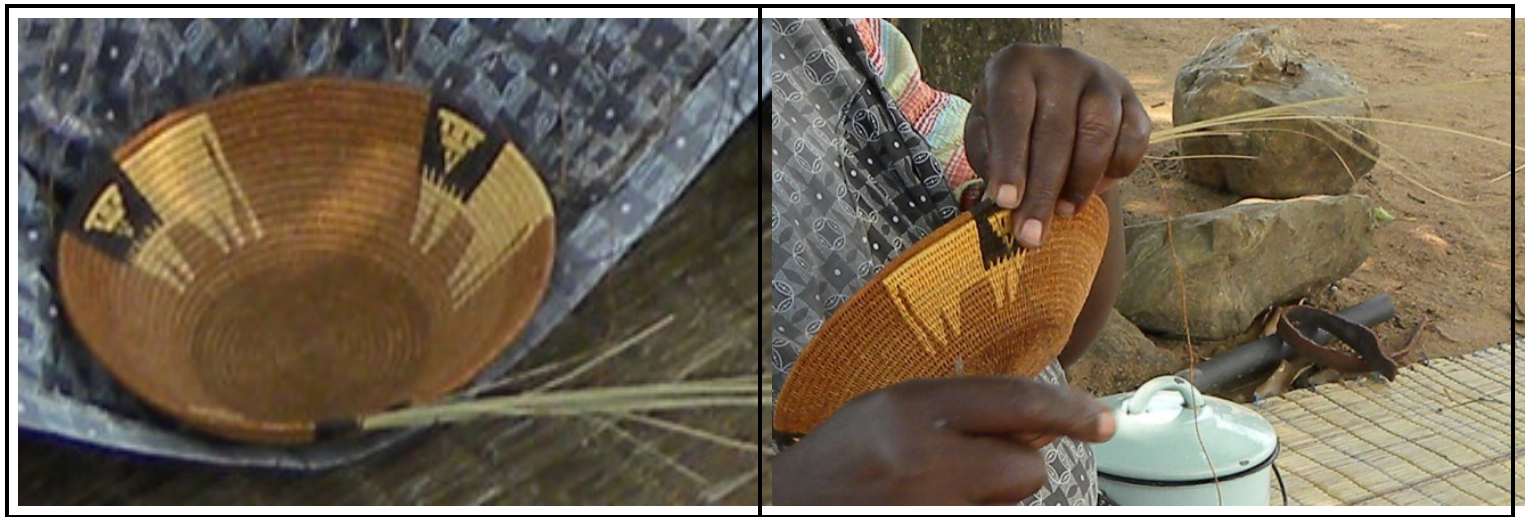

FIGURE 1: WEAVING A TITJA BASKET 
container of water with the thread or grass to be dyed. Empty paraffin tins are frequently used for this purpose. Iron pots, like those used for cooking, are not used. On rare occasions salt may be added but as a rule no mordant is used. The mixture is brought to boil and then left to simmer for two to three hours. The craftswomen from the Sashe-Limpopo area indicated that they leave their mixtures to boil for six to seven hours. The dyed materials are often left in the dye mixture overnight to absorb as much dye as possible.
The yarn or grass is then washed until the water runs clear and is then hung to dry in the sun. Dyeing is usually done in bulk in order to save time and resources.

\section{Identification of the natural dye-yielding plants}

The plants identified by the Ngimanodolo group are listed in Table I.

\section{TABLE 1: PLANTS USED OR KNOWN BY THE NGIMANODOLO GROUP AS DYE PLANTS}

\begin{tabular}{|l|l|l|l|}
\hline \multicolumn{1}{|c|}{ Scientific name } & \multicolumn{1}{|c|}{ Common name } & \multicolumn{1}{c|}{$\begin{array}{c}\text { SiSwati name } \\
\text { plant }\end{array}$} \\
\hline Acacia Karroo & Sweet thorn & Isinga & \multicolumn{1}{c|}{ it } \\
\hline Acacia sieberiana & Paperbark thorn & Shibha & 7 \\
\hline Aloe marlothii & Mountain aloe & Inhlaba & $3 ; 4 ; 7$ \\
\hline Antidesma venosum & Tassel berry & Inhlalamahubhulu & 4 \\
\hline Bauhinia galpinii & Pride-of-De-Kaap & Lusololo & 4 \\
\hline Bidens pilosa & Blackjack & Chuchuza & $1 ; 4$ \\
\hline Calpurnia aurea & Wild laburnum & Umphendulo & 4 \\
\hline Combretum molle & Velvet bushwillow & Umbhondvo & $3 ; 5 ; 6$ \\
\hline Euclea crispa & Blue guarri & Umdlelanyamatane & $1 ; 4 ; 5 ; 6$ \\
\hline llex mitis & African holly & Libota & 4 \\
\hline Pterocarpus angolensis & Wild teak & Umvangati & $1 ; 2 ; 4 ; 5$ \\
\hline Rhus dentata & Nana berry & Ihlangushane & \\
\hline Sclerocarya birrea & Uarula & Umganu & $3 ; 4 ; 5 ; 6 ; 7$ \\
\hline Solanum nigrum & Umsobo & $4 ; 5 ; 7$ \\
\hline Sterculia murex & Black nightshade & 4 \\
\hline Syzygium cordatum & Lowveld star chestnut & Umbhaba & $3 ; 4 ; 6 ; 7$ \\
\hline Tagetes minuta & Water berry & Umcozi & $4 ; 5 ; 7$ \\
\hline Trichilia emetica & Khaki weed & Nukane & $3 ; 4 ; 5$ \\
\hline Ziziphus mucronata & Natal mahogany & Umkhuhlu \\
\hline
\end{tabular}

1. Cardon, D. 2007

2. Coates-Palgrave, M. 2002

3. Cunningham, A.B. 1987

4. Dube, M.A. \& Musi, P.J. 2002

5. Long, C. 2005

6. Van Wyk, B-E. \& Van Wyk, P. 1997

7. Van Wyk, B.-E. \& Gericke, N. 2000

TABLE 2: $\quad$ FURTHER DATA ON DYE PLANTS: TIME OF YEAR AVAILABLE, PART OF PLANT USED; AND COLOUR OBTAINED FROM PLANT

\begin{tabular}{|c|c|c|c|}
\hline Scientific name & Time of year & Part used & Colour obtained \\
\hline Acacia Karroo & Throughout the year & Bark & Rust \\
\hline Acacia sieberiana & Throughout the year & Bark & Rust \\
\hline Aloe marlothii & Throughout the year & Roots & Yellow \\
\hline Antidesma venosum & Dec to March & Fruit & Pink \\
\hline Bauhinia galpinii & Dec to Feb & Flowers & Pink \\
\hline Bidens pilosa & Oct to June & Flowers/leaves & Yellow \\
\hline Calpurnia aurea & Oct to June & Leaves & Purple-brown \\
\hline Combretum molle & Sept to Nov & Leaves/flowers & Red \\
\hline Euclea crispa & Throughout the year & Roots & Yellow \\
\hline Ilex mitis & Throughout the year & Roots & Black \\
\hline Pterocarpus angolensis & Throughout the year & Bark & Red \\
\hline Rhus dentata & Feb to May & Fruit & Yellow \\
\hline Sclerocarya birrea & Throughout the year & Bark & Red \\
\hline Solanum nigrum & Dec to April & Fruit & Navy \\
\hline Sterculia murex & Throughout the year & Bark & Rust \\
\hline Syzygium cordatum & Throughout the year & Fruit/bark & Purple \\
\hline Tagetes minuta & Oct to May & Flowers/leaves & Yellow/green \\
\hline Trichilia emetica & Throughout the year & Bark & Rust \\
\hline Ziziphus mucronata & Throughout the year & Bark & Rust \\
\hline
\end{tabular}

Natural dyes and dyeing techniques used by craftswomen in the Northern Hhohho region of Swaziland 
As can be seen in Table 1, all of the plants except Rhus dentata have also been identified by other authors as dye plants. Six of these, Antidesma venosum, Bauhinia galpinii, Calpurnia aurea, Ilex mitis, Sterculia murex, and Ziziphus mucronata, have only been identified by one other source, namely Dube and Musi (2002). Since Dube and Musi worked specifically in Swaziland, one can conclude that these plants are not known or used as dye plants in other regions. Of these, Rhus dentata requires closer scrutiny and will be discussed in further detail later. Detailed information on the dye plants is contained in Table 2.

The leaves of the Calpurnia aurea were used to dye the darker coloured sisal thread in the small titja basket made by Ms Ngwenya for the researcher (see Figure 2). The Calpurnia aurea, also known as the common calpurnia or wild laburnum, grows abundantly as a shrub in the Mshingishi area, and the researchers were shown its leaves as well as those of the Bidens pilosa which were used to obtain the yellow dye for the basket in Figure 2. The Ngimanodolo group remarked that they combine the plant material from the Calpurnia aurea, the Syzygium cordatum (water berry) and the Euclea crispa (blue guarri) to obtain a much deeper royal purple than that obtained by using the plants separately. The use of more than one plant in the same dye pot in order to obtain a more intense colour was also reported by Cardon (2007:81) and Kala (2002).
When shown the photographs of the plants identified by the Ngimanodolo group as dye plants, the Mshingishi group recognised seven of those as plants used by them for dyeing, and one as a plant known to be a source of dye but not used as such by them. The results for the Mshingishi group are contained in Table 3.

Authentication of the identified plants as a source of dye.

Acacia Karroo Coates-Palgrave (2002), Van Wyk and Gericke (2000:247) and Long (2005) state that the bark of the Acacia Karroo (Sweet thorn) is used to tan leather and that it imparts a red colour to it. It is therefore quite possible that the bark could be used as a dye to obtain a rust colour in sisal, as stated by the Ngimanodolo group. The Mshingishi group did not recognise the Acacia Karroo from the photographs and clearly stated that they were not familiar with the tree. Cardon (2007:461-472) lists a number of Acacia species from the northern hemisphere from which mainly the pods, but sometimes the bark, are used for dyeing.

Acacia sieberiana Van Wyk and Gericke (2000:247) state that the bark of the Acacia sieberiana (Paperbark thorn) can be used to obtain a grey colour, while the Ngimanodolo group used the bark for a rust colour. Again the Mshingishi group did not recognise the tree.

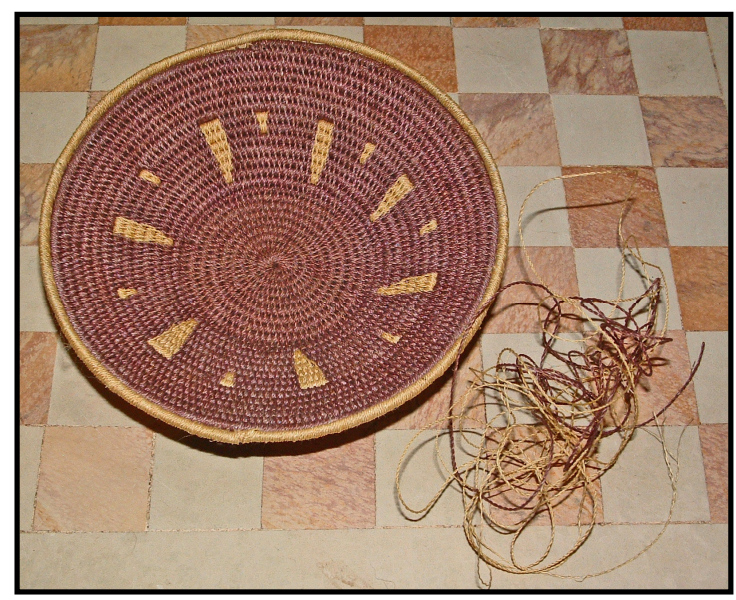

FIGURE 2: A TITJA BASKET MADE FROM SISAL DYED WITH EXTRACTS FROM CALPURNIA AUREA AND BIDENS PILOSA

TABLE 3: PLANTS USED OR KNOWN BY THE MSHINGISHI GROUP AS DYE PLANTS

\begin{tabular}{|l|l|l|}
\hline \multicolumn{1}{|c|}{ Scientific name } & \multicolumn{1}{|c|}{ Common name } \\
\hline Antidesma venosum & Tassel berry & \multicolumn{1}{c|}{ SiSwati name } \\
\hline Bauhinia galpinii & Pride-of-De-Kaap & Lusololo \\
\hline Bidens pilosa & Blackjack & Chuchuza \\
\hline Calpurnia aurea & Wild laburnum & Umphendulo \\
\hline Euclea crispa & Blue guarri & Umdlelanyamatane \\
\hline Pterocarpus angolensis & Wild teak & Umvangati \\
\hline Sclerocarya birrea & Marula & Umganu \\
\hline \multicolumn{2}{|c|}{ Plants known to be dye plants but not used for that purpose } \\
\hline \multicolumn{2}{|c|}{ Scientific name } & \multicolumn{2}{c|}{ SiSwati name } \\
\hline Rhus dentata & Nana berry name & Ihlangushane \\
\hline
\end{tabular}

Natural dyes and dyeing techniques used by craftswomen in the Northern Hhohho region of Swazi- 
Aloe marlothii Although the name inhlaba is used in siSwati to indicate a large number of different aloe plants, the botanist identified the Aloe marlothii (Mountain Aloe) as the specie used for dyeing in the Hhohho region. He confirmed this again when shown the photographs of different aloe species on a later occasion. Cunningham (1987) states that the roots of the Aloe marlothii are used to obtain a golden-yellow dye, while Van Wyk and Gericke (2000:248) say that numerous different aloe species, including the Aloe marlothii, are used as a dye source. They also state that the aloe is a sustainable dye source as the plants readily form new roots when replanted.

Antidesma venosum The Antidesma venosum (Tassel Berry) is one of the plants that only Dube and Musi (2002) also list as a dye source. Both the Ngimanodolo and Mshingishi groups identified it as a plant used by them. It is unclear if the fruits or bark and roots are the best to use, as the groups differed in that respect. Both claimed that a pink colour is obtained.

Bauhinia galpinii The well-known Bauhinia galpinii or Pride-of-De Kaap is another plant identified not only by Dube and Musi (2002), but also by both groups of craftswomen. As this plant is found in abundance over large areas of South Africa, it should not be difficult to verify if a pink colour can be obtained from the flowers as claimed.

Bidens pilosa Bidens pilosa (Blackjack) is used by both groups as a dye source. Both Dube and Musi (2002) and Cardon $(2007: 239$, 683) list it as a plant used in dyeing. The flowers or flowers and leaves will yield a yellow dye. This was also the plant used by Ms Ngwenya to obtain the yellow colour to use in the small titja basket (see figure 2). The leaves of bidens pilosa are commonly used as marog (spinach) in many parts of Southern Africa (Van Wyk \& Gericke 2000:68). This plant is not indigenous to Southern Africa and is considered a weed. As it is also an annual, there is not really a danger that its use will cause extinction.

Calpurnia aurea The Calpurnia aurea or wild laburnum, already briefly discussed earlier, is the other plant used in the making of the titja basket shown in Figure 2. This plant is also listed by Dube and Musi (2002) and used by both groups.

Combretum molle The flowers of the Combretum molle (velvet bushwillow) were identified by the Ngimanodolo but not the Mshingishi, group as a source of red dye. Cunningham (1987) states that the roots are sometimes, but not frequently, used to obtain a yellow-brown dye, while Van Wyk and Van Wyk (1997:334) say that the leaves yield a red and the roots a yellow-brown dye. Long (2005) lists the combretum molle as a source of red dye without stating which part of the plant is used. A different combretum species, the Combretum glutinosum, is used in Mali for dyeing the bogolan or mud cloths (Cardon, 2007:450; Toerien, 2003)
Euclea crispa The Euclea crispa (blue guarri) is used by both groups as a dye source. The Ngimanodolo group said that the roots provide a yellow dye, but a number of other authors (Cardon, 2007:81; Long, 2005; Van Wyk \& Van Wyk, 1997:340) state that a dark brown dye is obtained. The difference could be attributed to the fact that the craftswomen very rarely use a mordant. Dube and Musi (2002) list the blue guarri as a dye plant but give no information as to the colour obtained. Roots from the Euclea divinorum is widely acknowledged as a natural dye (Cardon, 2007:79; Coates-Palgrave, 2002:889; Cunningham, 1987; Van Wyk \& Gericke, 2000:252; Van Wyk \& Van Wyk, 1997:340). Cardon (2007:81) states that the fruit of the Euclea divinorum is mixed with that of the Berchemia discolor to obtain a rich purple-brown colour that is more fast than that obtained when used alone. Basket weavers from the Sashe-Limpopo region use only the bark from the Berchemia discolor, with no mordant, to dye the leaves of the Lala palm (Hyphaene petersiana) used in their basket ware a dark brown (Mokwena, 2008). The researcher has baskets such as these in her possession and practically no fading has taken place over a number of years, in contrast with baskets bought in the northern Kwa-Zulu Natal area in which the synthetic dyes have, over the same period of time, faded to very light and insipid colours.

Ilex mitis The roots of the llex mitis (African holly) was identified by the Ngimanodolo group but not the Mshingishi as a source of black dye. Dube and Musi (2002) are the only authors listing it as a natural dye.

Pterocarpus angolensis The Pterocarpus angolensis (Wild teak or African bloodwood) is widely recognized as a dye plant. Not only did both groups identify it as such, but Cardon (2007:299), CoatesPalgrave (2002:389), Dube and Musi (2002), Errington and Chisumpa (1986:10) and Long (2005) also list it. Coates-Palgrave remarks that a sticky, blood-like red sap is released when the tree is cut, and that this will permanently stain a textile that comes into contact with it.

Rhus dentata Dube and Musi (2002) only specify Rhus spp as a source of dye, but the botanist working in that area identified it by the siSwati name used by the women (ihlangushane), as Rhus dentata (Nana berry). According to Coates-Palgrave (2002:567) the fruit of the dentata is shiny red, and available from November to March. The women, on the other hand, made a yellow dye from fruit harvested from February to May. (See Table 2 for additional information on the part of the plant used; the months during which the plant is harvested ; and the colour obtained.) According to Long (2005) nearly all the Rhus subspecies are locally called ihlangushane. The women from the Mshingishi group were only shown photographs of Rhus dentata, and stated that although they know that it could be used as a dye plant, they themselves had never used it. Further investigation is needed to identify the specific Rhus species used in Swaziland. The Rhus group as a whole (also referred to as sumacs) is an important source of dyes and tannins in 
many parts of the world (Cardon, 2007:431-439) and they are therefore quite likely also used in Swaziland for that purpose. Most Rhus species growing in Africa have recently been placed in the genus Searsia.

Sclerocarya birrea Sclerocarya birrea, the wellknown marula tree, is also widely acknowledged as a dye plant. This is the tree that a number of Swazi salesladies of craft items could remember as a source of dye used by their mothers, grandmothers or other older relatives. It is listed by Cunningham (1987), Dube and Musi (2002), Long (2005), Van Wyk and Gericke (2000:258) and Van Wyk and Van Wyk (1997:446). The bark yields a pale brown, pink, mauve or red dye.

Solanum nigrum The Solanum nigrum or black nightshade is not indigenous to Southern Africa. The berries are used to produce a dark blue shade. Dube and Musi (2002), Long (2005) and Van Wyk and Gericke (2000:258) acknowledge this as a dye plant. Interestingly, the women from the Mshingishi group did not know it as a source of dye. Since both the ripe berries and the leaves are eaten as food (Van Wyk \& Gericke 2000:56), it could be that this plant is too valuable as food source to be utilised for other purposes. The unripe berries are poisonous.

Sterculia murex The Sterculia murex (Lowveld star chestnut) is only identified by the Ngimanodolo group and Dube and Musi (2002). The bark produces a rust colour.

Syzygium cordatum The bark of the Syzygium cordatum or Water berry yields a red-brown dye while the fruit is used as a purple dye (Cunningham, 1987; Dube \& Musi, 2002; Van Wyk \& Van Wyk,1997:320; Van Wyk \& Gericke, 2000:258).

Tagetes minuta Tagetes minuta, the well-known Khaki weed, is another alien plant used as a dye source. The flowers and leaves are used to produce a yellow or green colour. This plant is listed by Dube and Musi (2002); Long (2005) and Van Wyk and Gericke (2000:258). The latter illustrate ten different shades that can be obtained from the flower heads of tagetes minuta, depending on the mordant used. The unmordanted colour is labelled pinard yellow, and the mordanted colours vary from old gold, olive and grey green to maroon and Morocco red.

Trichilia emetica The bark of the Trichilia emetica (Natal mahogany) will, according to the ladies from the Ngimanodolo group, produce a rust colour. It is also listed by Dube and Musi (2002). Cunningham (1987) states that it is used to obtain a light red-brown colour while Long (2005) describes the colour as pink.

Ziziphus mucronata The bark of the Ziziphus mucronata (Buffalo thorn) was identified as a source of rust dye by the Ngimanodolo group. It is also listed by Dube and Musi (2002).

\section{LIMITATIONS}

The main limitation of this study is the uncertainty whether the plant as identified by vernacular name by the craftswomen and named by the botanist, is really the actual species used as dye source. Both the coresearcher and the botanist are from the area, and have knowledge of dye techniques and plants used. Information was also cross-checked with other authors on Swazi dye plants, such as Dube and Musi (2002) and Long (2005). An ideal situation would have been to have the dyers identify the plant and then to have the species or subspecies verified at a herbarium, but with the death of the group leader and subsequent end of the use of natural dyes, this has become virtually impossible to achieve.

This study also made no attempt to address the issue of sustainability or possible damage to the natural flora and biodiversity of the region. There are those that strongly support the use of natural dyes on the grounds of eco-friendliness ( Bechtold et al, 2003; Bechtold et al, 2006; Bechtold et al, 2007; Deo \& Desai, 1999; Gilbert \& Cooke, 2001; Kamel et al, 2005; Mahanta \& Tiwari, 2005; Türkmen et al, 2004), but then there are also studies that highlight the detrimental effects the harvesting of natural products can have on the environment (Cunningham \& Milton, 1987; Cunningham, 1987; Cunningham 1994). Different ways of lessening this negative impact have been suggested (Cardon, 2007:3; Cunningham, 1994; Errington \& Chisumpa, 1986:26). In the light of the diminishing use of natural dyes in Swaziland, it is doubtful that the activities of the craftswomen have any significant influence on their natural surroundings.

\section{CONCLUSION}

It seems as if the method and procedure used by the craftswomen from Swaziland, namely direct dyeing, is an acceptable and well-known technique not only in Southern Africa, but also elsewhere in the world. Crushing the plant material and then boiling it with the fibres to be dyed seems to be the method of choice in both the Sashe-Limpopo region and the Maputaland coastal plain.

One of the objectives of this study was to authenticate the use of the identified plants by other authors. Of all the plants, only Rhus dentata has not been identified by any other source, and this specie, as stated before, needs further investigation. Of the dye plants identified by the Ngimanodolo group, six (Antidesma venosum, Bauhinia galpinii, Calpurnia aurea, Ilex mitis, Sterculia murex, and Ziziphus mucronata,) have only been identified by Dube and Musi (2002). Dube and Musi supplied no information on the part of the plant used, the season that it was obtained in, or the colour yielded. In these respects this study therefore revealed information on natural dyes that is in danger of being lost forever.

Judging by the results of the 2009-2010 surveys, it seems as if very few, if any, craftswomen are still using natural dyes. Further research is needed to 
establish if any additional plants are/were used by other, to now unidentified, groups, and also if all the plants identified will yield the dyestuff claimed. Such studies play an important role in ensuring that the indigenous knowledge practices of southern Africa will be preserved.

\section{REFERENCES}

AKÇAKOCA KUMBASAR, EP, ATAV, R \& BAHTIYARI, MI. 2009. Effects of alkali proteases properties of various proteinous materials with natural dyes. Textile Research Journal 79(6):517-525.

BECHTOLD, T, MAHMUD-ALI, A \& MUSSAK, R. 2007. Natural dyes for textile dyeing: A comparison of methods to assess the quality of Canadian goldenrod plant material. Dyes and Pigments 75(2):287-293.

BECHTOLD, T, MUSSAK, R, MAHMUD-ALI, A, GANGLBERGER, E \& GEISSLER, S. 2006. Extraction of natural dyes for textile dyeing from coloured plant wastes released from the food and beverage industry. Journal of the Science of Food and Agriculture 86:233-242.

BECHTOLD, T, TURCANU, A, GANGLBERGER, E \& GEISSLER, S. 2003. Natural dyes in modern textile dyehouses - how to combine experiences of two centuries to meet the demands of the future? Journal of Cleaner Production 11(5):499-509.

BLANC, R, ESPEJO, T, LÓPEZ-MONTES, A, TORRES, D, CROVETTO, G, NAVALÓN, A \& VÍLCHEZ, J L. 2006. Sampling and identification of natural dyes in historical maps and drawings by liquid chromatography with diode-array detection. Journal of Chromatography $A$ 1122:105-113.

CARDON, D. 2007. Natural dyes: Sources, tradition, technology and science. London. Archetype.

CASAS-CATALÁN, MJ \& DOMÉNECH-CARBÓ, MT. 2005. Identification of natural dyes used in works of art by pyrolysis-gas chromatography/mass spectrometry combined with in situ trimethylsilylation. Analytical \& Bioanalytical Chemistry 382:259-268.

COATES-PALGRAVE, M. 2002. Keith CoatesPalgrave Trees of Southern Africa.3rd ed. Cape Town. Struik.

CRISTEA, D, \& VILAREM, G. 2006. Improving light fastness of natural dyes on cotton yarn. Dyes and Pigments 70(3):238-245.

CUNNINGHAM, AB \& MILTON, SJ. 1987. Effects of basket-weaving industry on mokola palm and dye plants in northwestern Botswana. Economic Botany 41(3):386-402.

CUNNINGHAM, AB. 1987. Commercial craftwork: Balancing out human needs and resources. South African Journal of Botany 53(4):259-266.

CUNNINGHAM, AB. 1994. Integrating local plant resources and habitat management. Biodiversity and Conservation 3:104-115.

DEO, HT, \& DESAI, BK. 1999. Dyeing of cotton and jute with tea as natural dye. Journal of the Society of Dyers and Colourists 115:224-227.

DOĞAN, Y, BAŞLAR, S, MERT, HH \& AY, G. 2003. Plants used as natural dye sources in Turkey. Economic Botany 57(4):442-453.

DUBE, MA \& MUSI, PJ. 2002. Analysis of indigenous knowledge in Swaziland: implications for sustainable agricultural development. ATPS Working Paper Series No. 34.

DWECK, AC. 2002. Natural ingredients for colouring and styling. International Journal of Cosmetic Science 24:287-302.

FENG, XX, ZANG, LL, CHEN, JY \& ZHANG, JC. 2007. New insights into solar UV-protective properties of natural dye. Journal of Cleaner Production 15 (4):366-372.

ERRINGTON, E \& CHISUMPA, SM. 1986. Natural dyes of Zambia. Ndola. Mission Press.

FERREIRA, ESB, HULME, AN, McNAB, H \& QUYE, A. 2004. The natural constituents of historical textile dyes. Chemical Society Reviews 33:329-336.

GERMISHUIZEN, G, MEYER, NL, STEENKAMP, Y \& KEITH, M (eds). 2006. A checklist of South African plants. Southern African Botanical Diversity Network Report No. 41. SABONET, Pretoria.

GILBERT, KG \& COOKE, DT. 2001. Dyes from plants: past usage, present understanding and potential. Plant Growth Regulation 34:57-69.

GULRAJANI, ML, SRIVASTAVA, RC, \& GOEL, M. 2001. Colour gamut of natural dyes on cotton yarns. Coloration Technology 117:225-228.

GULRAJANI, ML. 2001. Present status of natural dyes. Indian Journal of Fibre and Textile Research 26:191-201.

HILL, DJ. 1997. Is there a future for natural dyes? Review of Progress in Coloration and Related Topics 27:18-25.

KALA, PK. 2002. Indigenous knowledge of Bhotiya tribal community on wool dyeing and its present status in the Garhwal Himalaya, India. Current Science 83(7):814-817

KAMEL, MM, EL-SHISHTAWY, RM, YUSSEF, BM \& MASHALY, H. 2005. Ultrasonic assisted dyeing: dyeing of wool with lac as natural dye. Dyes and Pigments 65:103-110.

KARAPANAGIOTIS, I. 2006. Identification of indigoid natural dyestuffs used in art objects by HPLC coupled to APCI-MS. American Laboratory 38(3):36-40.

LONG, C. 2005. Swaziland's flora - siSwati names and uses. Swaziland National Trust Commission. http://www.sntc.org.sz/flora/chrislong.asp 18 May 2009.

MACFOY, C. 2004. Ethnobotany and sustainable utilization of natural plants in Sierra Leone. Economic Botany 58:S66-S76.

MAHANTA, D \& TIWARI, SC. 2005. Natural dyeyielding plants and indigenous knowledge on dye preparation in Arunachal Pradesh, northern India. Current Science 88(9):1474-1480.

MOKWENA, J. 2008. Personal communication. 3 July, Samaria, Vhembe.

POLAKOFF, C. 1982. African textiles and dyeing techniques. London. Routledge.

PUROHIT, A, MALLICK, S, NAYAK A, DAS, N, NANDA, B \& SAHOO, S. 2007. Developing multiple dyes from flower parts of Gulmohur. Current Science 92(12):1681-1682.

SARKAR, AK \& SEAL, CM. 2003. Color strength and colorfastness of flax fabrics dyed with natural colorants. Clothing and Textiles Research Journal 21 (4):162-166.

SIVA, R. 2007. Status of natural dyes and dye- 
yielding plants in India. Current Science 92(7):916925.

STEWART, DW \& SHAMDASANI, PN. 1990. Focus groups: theory and practice. London. Sage.

SUROWIEC, I, QUYE, A \& TROJANOWICZ, M. 2006. Liquid chromatography of natural dyes in extracts from historical Scottish textiles excavated from peat bogs. Journal of Chromatography A 1112:209217.

TOERIEN. ES. 2003. Mud cloth from Mali: Its making and use. Journal of Family Ecology and Consumer Sciences 31:52-57.

TÜRKMEN, N, KIRICI, S, ÖZGÜVEN, M, INAN, M \& KAYA, DA. 2004. An investigation of dye plants and their colourant substances in the eastern Mediterranean region of Turkey. Botanical Journal of the Linnean Society 146:71-77.

VAN JAARSVELD, E. 2007. Volksname hoef nie by reëls te hou nie. Huisgids. Die Beeld. 16 February:32 VAN WYK, B-E \& VAN WYK, P. 1997. Field guide to trees of Southern Africa. Cape Town. Struik.

VAN WYK, B.-E \& GERICKE, N. 2000. People's plants: A guide to useful plants of Southern Africa. Pretoria. Briza.

VANKAR, PS. 2000. Chemistry of natural dyes. Resonance October 2000:73-80. 